\title{
Effect of squid hydrolysate and squid powder on the quality characteristics of dried noodles with squid
}

\author{
Mi-Soon Jang*, Ji-In Park, Yeon Gyeom Jeong, Kil Bo Shim \\ Food Safety and Processing Research Division, \\ National Institute of Fisheries Science, Busan 46083, Korea
}

\section{오징어 가수분해물과 오징어 분말 첨가가 오징어 건면의 품질특성에 미치는 영향}

\author{
장미순*·박지인 · 정연겸 · 심길보 \\ 국립수산과학원 식품위생가공과
}

\begin{abstract}
This study aimed the quality characteristics of dried noodles with squid (SDN) using squid enzyme hydrolysate and steamed and dried squid powder (SP) to obtain basic data for developing SDN with excellent taste, flavor and nutritive value. Since commercially available squid enzyme hydrolysates containing protease NP (P-NP) display high values of protein yield, 'brix, and degree of hydrolysis, P-NP was used herein for squid hydrolysis. SP obtained through steaming for $20-30 \mathrm{~min}$ at $100^{\circ} \mathrm{C}$ and then drying $\left(50-65^{\circ} \mathrm{C}\right)$ to obtain a high yield of unsaturated fatty acids and free amino acids. SDN were prepared using $0,5,10,15$ and $20 \% \mathrm{SP}$ and $45 \% \mathrm{SH}$ on a wheat-flour basis. The SDN had higher crude protein and crude lipid contents than the control(not treated with SH and SP). The $L$ value was lower in the SDN than in the control, while the a and $b$ values significantly increased with an increase in SP content $(\mathbf{p}<\mathbf{0 . 0 5})$. Cooking properties (including weight, volume, and water absorption) and turbidity were significantly enhanced in the SDN rather than the control $(p<0.05)$. The taurine content of SDN increased with an increase in SP content $(\mathbf{p}<\mathbf{0 . 0 5})$. The odor intensity significantly increased in the SDN rather than the control $(\mathbf{p}<\mathbf{0 . 0 5})$. The present results indicate that it is possible to prepare SDN in consideration of the health and flavor preference of consumers.
\end{abstract}

Key words : squid, noodles, quality, powder, hydrolysate

\section{서 론}

오징어는 독특한 조직감과 풍미로 인해 한국, 중국 및 일본 등 동아시아인들이 즐겨 소비하는 수산물 중의 하나로 서, 단백질 함량이 높고 타우린, 글루탐산 등과 같은 유리아 미노산 함량도 풍부하다. 또한 오징어의 지방 함량은 $1 \%$ 이하로 낮지만 그 중 고도불포화지방산 함량은 절반 이상을

*Corresponding author. E-mail : suni1@korea.kr Phone : 82-51-720-2651, Fax : 82-51-720-2669

Received 04 September 2019; Revised 01 October 2019; Accepted 02 October 2019.

Copyright (c) The Korean Society of Food Preservation. All rights reserved.
차지하고 있으며, 특히 n-3 지방산인 eicosapentaenoic acid (EPA) 및 docosahexaenoic $\operatorname{acid}(\mathrm{DHA})$ 의 함량이 대부분을 차지하고 있는 것으로 알려져 있다(1). 오징어는 지금까지 우리의 식탁에서 반찬 및 술안주와 같은 부식 및 간식의 개념으로 주로 애용되어 왔으나, 이제는 한 끼 식사를 해결 할 수 있는 웰빙형 주식으로 개발하여 오징어 가공식품의 고부가가치를 창출 할 필요가 있다.

이와 같은 관점에서 우리나라 소비자들의 식품 소비 형 태를 조사한 결과, 인구, 사회 구조의 변화 등으로 인해 간편 식품구입이 급증하고 있으며, 이 중 밥 대신 간편하게 먹을 수 있는 면류 제품에 대한 한국인 1 인당 소비량은, 2010 년 $12.4 \mathrm{~kg}$ 에서 2014년에는 $13.3 \mathrm{~kg}$ 으로 증가할 만큼, 우리의 식생활 속에서 면류소비는 점점 증가하고 있는 것으 
로 나타났다(2). 면류 시장은 라면과 같은 유탕면 시장이 아직까지도 주류를 차지하고 있지만, 최근 고령화 및 웰빙 식문화의 확산으로 인해 튀기지 않은 건면 시장이 대세로 등장함에 따라 건강한 면, 염도 및 칼로리가 낮은 면과 같이 건강에 좋은 프리미엄 면제품을 개발하기 위해 기업들이 치열하게 경쟁하고 있다. 특히, 전 세계 소비자들이 체중감 량을 위한 다이어트, 식이요법 등에 관심이 증가하면서 탄 수화물 함량이 높은 밀가루를 대체할 수 있는 쌀, 천연재료 등을 사용한 면류 제품이 등장하고 있다.

이에 최근에는 기존의 밀가루를 사용한 국수의 단점을 보완하기 위해, 탄수화물 함량을 낮추고 무기질, 비타민, 아미노산 함량 등을 높여 영양학적으로 우수한 면류를 제조 하는 방법과 관련하여 다양한 기술개발이 추진되고 있다. 예를 들어, 파프리카 분말을 첨가한 국수의 특성(3), 매생이 가루를 첨가한 쌀국수 제조방법(4), 야콘과 헛개나무 추출 액을 이용하여 즉석 쌀국수를 제조하는 방법(5), 강황, 자색 고구마 및 톳을 첨가한 쌀국수 품질특성(6) 및 부추 및 미나 리 첨가 국수(7) 등이 연구 보고되어 있다. 또한 오징어를 이용하여 면류를 제조하는 기술도 개발되고 있는데 분쇄된 생오징어 육을 주원료로 하고, 강력분 밀가루, 쌀가루 등을 수분조정제로 활용하여 밀가루 사용량을 줄임으로써, 밀가 루에 부족한 아미노산 등을 보충한 오징어국수 제조방법(8) 이 보고되어 있고, 오징어 분말과 뽕잎 분말을 첨가하여 오징어 국수를 제조하는 방법(9)이 보고되어 있다. 그리고 오징어 먹물과 갑오징어 빼 가루를 첨가한 오징어먹물국수 제조방법(10), 오징어를 초퍼에 넣어 마쇄한 오징어 마쇄물 과 오징어 먹물을 혼합한 반죽을 사용하여 오징어를 포함한 면의 제조방법(11)도 보고되어 있다.

위의 보고된 연구들은 일반 면류 제품에 비해 단백질 등 영양학적으로 보완된 측면은 있지만 맛과 풍미가 향상된 오징어 면의 제조에 대한 연구보고는 미비한 실정이다. 일 반적으로 어육단백질의 효소 가수분해물은 화학적으로 다 양한 사이즈로 분해되어 생리활성을 나타낼 뿐만 아니라 다른 동식물에서는 찾아볼 수 없는 독특한 정미성분과 향기 성분을 지니고 있는 것으로 보고되고 있으며(12), 단백질에 효소를 처리하여 가수분해시킴으로서 식품소재로 활용하 려는 연구가 많이 시도되고 있다(13).

따라서 본 연구에서는 맛과 풍미가 우수한 오징어 건면 을 제조하고자 오징어의 효소 가수분해물과 증숙 및 건조과 정을 거친 오징어 분말을 사용하여 오징어 건면의 가공조건 및 품질특성에 관하여 살펴보았다.

\section{재료 및 방법}

\section{재 료}

본 실험에 사용한 살오징어(Todarodes pacificus)는 대형
기선저인망수협에서 공급받아 일정량씩 포장한 후 냉동고 $\left(-25^{\circ} \mathrm{C}\right)$ 에 보관하여 사용하였다. 오징어의 가수분해물을 제 조하기 위하여 사용한 시판 상업효소인 Alcalase ${ }^{\circledR} 2.4$ L(Alc), trypsin(Try), pepsin(Pep)은 Sigma-Aldrich Co.(St. Louis, MO, USA)에서 구입하였고, Neutrase(Neu), Protamex(Pro), Flavourzyme 1,000 mg(Fla)은 Novo Co. (Novozyme Laboratories, Copenhagen, Denmark)에서 구입 하였다. Protease NP(P-NP)는 Pacific Pharmaceuticals Co. (Seoul, Korea)에서 구입하였다.

\section{효소 가수분해물의 단백질 농도, ${ }^{\circ} \mathrm{Brix}$ 및 가수분해도}

해동한 오징어의 내장은 제거하되 껍질은 제거하지 않은 오징어 마쇄육의 중량대비 증류수를 $1: 4(\mathrm{w} / \mathrm{w})$ 의 비율로 가 하고 균질화한 후, 시판 상업효소 7종(Alc, Try, Pep, Neu, Pro, Fla, P-NP)을 오징어 단백질 함량의 $1 \%$ 가 되도록 처리 하여 각 효소의 최적온도와 $\mathrm{pH}$ 에서 8시간동안 반응시켰다. 이들 가수분해효소의 최적온도와 $\mathrm{pH}$ 는 구입회사에서 제시 한 바에 따라 $\operatorname{Alc}\left(50^{\circ} \mathrm{C}, \mathrm{pH} 7\right), \operatorname{Try}\left(37^{\circ} \mathrm{C}, \mathrm{pH}\right), \operatorname{Pep}\left(37^{\circ} \mathrm{C}\right.$, $\mathrm{pH} 2), \mathrm{Neu}\left(50^{\circ} \mathrm{C}, \mathrm{pH} 6\right), \operatorname{Pro}\left(50^{\circ} \mathrm{C}, \mathrm{pH} 7\right), \mathrm{Fla}\left(50^{\circ} \mathrm{C}, \mathrm{pH} 7\right)$, $\mathrm{P}-\mathrm{NP}\left(50^{\circ} \mathrm{C}, \mathrm{pH}\right.$ 7)로 하였다. 이어서 $100^{\circ} \mathrm{C}$ 에서 10 분간 가열 처리하여 효소를 불활성화한 후 원심분리 $(1,631 \times \mathrm{g}, 15 \mathrm{~min})$ 하고 상등액을 취하여 단백질 농도, ${ }^{\circ} \mathrm{Brix}$ 및 가수분해도를 측정하였다.

단백질 농도는 Biuret assay(14)로 분석하였고, ${ }^{\circ} \mathrm{Brix}$ 는 굴절당도계(Atago dal-2, Atago Co., Ltd., Tokyo, Japan)를 사용하여 측정하였다. 가수분해도는 가수분해물에 동량의 $20 \%(\mathrm{w} / \mathrm{v})$ trichloroacetic acid(TCA)를 가하여 15 분간 균질 화한 후 여과하는 조작을 2 회 반복하고 원심분리하여 여과 한 상등액의 일정량을 Micro Kjeldahl법으로 정량하여 측정 하였으며, 계산은 총질소에 대한 $10 \% \mathrm{TCA}$ 가용성 질소의 상대비율(\%)로 하였다(15).

\section{단백질분해효소의 최적농도 및 분해시간 설정}

단백질분해능이 가장 뛰어난 효소의 최적농도와 분해시 간을 설정하기 위해 구입회사에서 제시한 최적온도와 $\mathrm{pH}\left(50^{\circ} \mathrm{C}, \mathrm{pH}\right.$ 7)에서 반응시켰다. 즉, 기질 농도의 $0.05,0.5$, 1 및 $2 \%$ 로 효소농도를 처리하여 48 시간동안 반응시킨 후 분해된 단백질 양은 $1,613 \times \mathrm{g}$ 에서 30 분간 원심분리하고 상 등액을 취하여 분석하였다.

\section{오징어의 분말의 제조}

냉동 오징어를 유수 해동하고, 껍질을 제거하지 않은 오 징어 육(오징어 다리, 몸, 귀)을 $100^{\circ} \mathrm{C}$ 에서 각각 1-2분, 8-10 분 및 20-30분 증숙하고, 상온에서 식힌 다음 오징어 육 두께가 $1 \mathrm{~cm}$ 정도 되도록 세절한 후, 각각의 시료를 $35^{\circ} \mathrm{C}$, $50^{\circ} \mathrm{C}$ 및 $65^{\circ} \mathrm{C}$ 로 설정된 열풍건조기(KED-066A, Kiturami, Gwangju, Korea)를 사용하여 건조를 실시하였다. 대조구로 
는 증숙처리 하지 않은 오징어를 각각 $35^{\circ} \mathrm{C}, 50^{\circ} \mathrm{C}$ 및 $65^{\circ} \mathrm{C}$ 에 서 건조한 것으로 하여 사용하였다. 건조가 완료된 오징어 시료는 분쇄기(DSCH-550SVS, Dusan Co., Ltd., Daegu, Korea)를 사용하여 분말형태로 제조하였다.

\section{오징어의 건면의 제조}

오징어 가수분해물과 오징어 분말을 각각 일정량 첨가하 여 제조한 오징어 면 재료의 배합비는 Table 1 과 같다. 오징 어 분말 첨가량은 밀가루의 중량대비 각각 $5 \%, 10 \%, 15 \%$ 및 $20 \%$ 를 첨가하여 혼합물을 제조하였고 밀가루, 오징어 분말 및 오징어 가수분해액을 혼합한 중량 $(145 \mathrm{~g})$ 의 $1 \%$ 에 달하는 소금 $1.45 \mathrm{~g}$ 을 오징어 가수분해물에 용해시킨 다음, 물 대신 첨가하여 반죽기(KVL $4100 \mathrm{~S}$, Kenwood Ltd., Hampshire P09 2NH, Havant, England)로 20분간 반죽하였 다. 이 때 사용한 가수분해물은 면의 적절한 물성 유지를 위해 $50-55^{\circ} \mathrm{C}$ 의 온도로 가온한 상태의 것을 사용하였고 대 조구는 오징어 분말 및 오징어 가수분해물을 사용하지 않기 에 밀가루와 물을 혼합한 중량 $(145 \mathrm{~g})$ 의 $2 \%$ 에 달하는 소금 $2.9 \mathrm{~g}$ 을 물에 녹여 사용하였다. Table 1과 같은 비율로 배합 한 반죽물을 비닐팩에 넣어 $5-10^{\circ} \mathrm{C}$ 의 저온에서 8 시간 숙성 시킨 다음, 제면기(Marcato Atlas 150, Marcato S.r.1, Campodarsego, Italy)의 반죽투입구에 넣어 반죽압출부의 히터를 90-100 ${ }^{\circ} \mathrm{C}$ 로 유지하면서 면발을 익히고 $15 \mathrm{~cm}$ 길이 로 절단하여 일광이 들지 않고 바람이 잘 통하는 서늘한 곳에 24시간 건조시킨 것을 오징어 건면 시료로 하여 분석 에 활용하였다.
Switzerland)을 사용하여 분석하였으며, 조지방은 ethyl ether을 이용한 Soxhlet 추출법, 조회분은 $550^{\circ} \mathrm{C}$ 건식 회화법 으로 측정하였다. 탄수화물의 경우 수분, 조단백질, 조지방 및 조회분 값을 모두 합하여 100 을 뺀 나머지로 하였다. 모든 측정은 3 회 반복 측정하여 평균값 \pm 표준편차로 나타내 었다.

\section{색도 측정}

색도는 오징어 건면을 분말화하여 투명 용기에 넣고 광 전비색계(Minolta CR-400, Konica Minolta. Inc., Osaka, Japan)를 사용하여 명도(lightness, L), 적색도(redness, a), 황색도(yellowness, b)를 3회 반복하여 측정하였다. 이때 사 용된 표준 백색판의 값은 $\mathrm{L}=93.09, \mathrm{a}=-0.74, \mathrm{~b}=3.98$ 이었다.

\section{수분결합능력(Water binding capacity, WBC)}

수분결합능력은 오징어 건면을 분쇄한 시료 $1 \mathrm{~g}$ 에 증류 수 $20 \mathrm{~mL}$ 를 가하여 1 시간동안 교반하고 원심분리 $(10,192 \times \mathrm{g}, 20$ 분 $)$ 한 후, 상등액을 제거하고 침전물의 무게 를 측정하여 처음 시료량과의 중량비로부터 수분결합능력 을 계산하였다(17).

$$
\text { 수분결합능력 }(\mathrm{WBC}, \%)=\frac{\text { 침전 후 시료 무게 }(\mathrm{g})}{\text { 처음 시료 무게 }(\mathrm{g})} \times 100
$$

Table 1. Formula for preparation of squid noodles containing squid hydrolysate and squid powder

\begin{tabular}{cccccc}
\hline \multirow{2}{*}{ Material } & \multicolumn{5}{c}{ Squid noodle } \\
\cline { 2 - 6 } & Control & SN 1 & SN 2 & SN 3 & SN 4 \\
\hline Wheat flour & $100 \mathrm{~g}$ & $95 \mathrm{~g}$ & $90 \mathrm{~g}$ & $85 \mathrm{~g}$ & $80 \mathrm{~g}$ \\
Squid powder & - & $5 \mathrm{~g}$ & $10 \mathrm{~g}$ & $15 \mathrm{~g}$ & $20 \mathrm{~g}$ \\
Water & $45 \mathrm{~g}$ & - & - & - & - \\
Squid hydrolysate & - & $45 \mathrm{~g}$ & $45 \mathrm{~g}$ & $45 \mathrm{~g}$ & $45 \mathrm{~g}$ \\
Salt & $2.9 \mathrm{~g}$ & $1.45 \mathrm{~g}$ & $1.45 \mathrm{~g}$ & $1.45 \mathrm{~g}$ & $1.45 \mathrm{~g}$ \\
\hline Total & $147.9 \mathrm{~g}$ & $146.45 \mathrm{~g}$ & $146.45 \mathrm{~g}$ & $146.45 \mathrm{~g}$ & $146.45 \mathrm{~g}$ \\
\hline
\end{tabular}

${ }^{1)}$ Control, squid noodle without squid hyrolysate and squid powder; SN 1, squid noodle with squid hyrolysate $45 \%$ and squid powder $5 \%$ based on wheat flour weight; SN 2, squid noodle with squid hyrolysate $45 \%$ and squid powder $10 \%$ based on wheat flour weight; SN 3, squid noodle with squid hyrolysate $45 \%$ and squid powder $15 \%$ based on wheat flour weight; SN 4, squid noodle with squid hyrolysate $45 \%$ and squid powder $20 \%$ based on wheat flour weight.

\section{일반성분 분석}

오징어 건면의 일반성분 측정은 $\mathrm{AOAC}$ 방법(16)으로 측 정하였다. 수분은 $105^{\circ} \mathrm{C}$ 의 dry oven(Venticell 222, MMM Medcenter Einrichtungen GmbH, München, Germany)에서 4시간 건조 후 방냉하고 무게를 측정하였고, 조단백질 $(\mathrm{N} \times 6.25)$ 은 Auto Kjeldahl system(Bunchi B-324/435/124, Frawill, Switzerland; Metrohm 8-719/806, Herisau,

\section{용해도 및 팽윤력}

용해도 및 팽윤력은 오징어 건면을 분쇄한 시료 $0.5 \mathrm{~g}$ 을 $50 \mathrm{~mL}$ 의 원심분리관에 취하고 증류수 $30 \mathrm{~mL}$ 를 가하여 $50^{\circ} \mathrm{C}$ 의 항온수조(LSB-051SK, Daihan Labtech Co., Ltd., Namyangju, Korea)에서 30 분간 진탕한 후, 원심분리 하여 얻은 상등액을 $105^{\circ} \mathrm{C}$ 에서 12 시간 건조하여 얻은 고형물을 측정하여 계산하였다(18). 


$$
\begin{aligned}
& \text { 용해도 }(\%)=\frac{\text { 상등액을 건조한 고형물의 무게 }(\mathrm{g})}{\text { 처음 시료 무게 }(\mathrm{g})} \times 100 \\
& \text { 팽윤력 }(\%)=\frac{\text { 원심분리 후의 무게 }(\mathrm{g})}{\text { 처음 시료 무게 }(\mathrm{g}) \times\left(100-\frac{8}{8} \text { 해도 }\right)} \times 100
\end{aligned}
$$

\section{조리 특성}

오징어 건면 $50 \mathrm{~g}$ 을 증류수 $500 \mathrm{~mL}$ 의 끊는 증류수에 넣고 3 분간 조리한 후, 철망으로 건져 3분간 물을 뺀 무게로 면의 중량, 부피, 수분흡수율 및 국물의 탁도를 측정함으로 써 제조된 면의 조리 특성을 조사하였다. 오징어 면의 중량 은 삶아서 건진 면을 건져 3 분간 물빼기 한 후의 무게로 계산하였고, 면의 부피는 중량을 측정한 후, 증류수 300 $\mathrm{mL}$ 를 채운 메스실린더에 면을 담근 후 증가한 물의 부피로 측정하였다. 조리한 국물의 탁도는, 오징어 면을 삶고 난 후의 국물을 실온에서 식힌 뒤 UV/Vis-spectrophotometer (US/MQX200, Biotek Instrument, Inc., Winooski, VT, USA) 를 이용하여 $675 \mathrm{~nm}$ 에서 흡광도를 측정하였다. 또한 오징 어 면의 수분흡수율은 다음 식에 의해 구하였다.

$$
\text { 수분흡수율 }(\%)=\frac{\text { 조리한 오징어 면의 중량-조리 전 오징어 면의 중량 }}{\text { 조리 전 오징어 면의 중량 }} \times 100
$$

\section{타우린 함량}

오징어 효소 가수분해물 및 오징어 분말 첨가량 별로 제조한 오징어 건면의 각각에 대한 타우린의 함량을 측정하 기 위하여 Taurine Assay Kit(BioVision, Milpitas, CA, USA) 을 사용하였다. 실험에 사용된 각 solution은 kit protocol에 따라 제조하여 사용하였다. 각 물질은 희석 가능한 양을 조절하였으며 powder시료의 경우 $0.01 \mathrm{~g}$ 을 취하여 $1 \mathrm{X}$ working solution $1 \mathrm{~mL}$ 에 용해 시켰고 액상 시료의 경우 $25 \mu \mathrm{L}$ 에 $1 \mathrm{X}$ working solution $155 \mu \mathrm{L}$ 를 혼합하였다. $1 \mathrm{X}$ working solution의 경우 $1 \mathrm{~mL}$ 기준으로 $1 \mu \mathrm{L}$ enzyme cofactor와 7.5 ascorbic acid를 첨가하였다. 96-well 기준으 로 각 군당 시료가 혼합된 solution을 $180 \mu \mathrm{L}$ 씩 분주한 후 enzyme mix $20 \mu \mathrm{L}$ 첨가하여 $30^{\circ} \mathrm{C}, 30$ 분 반응하였으며 sulfite probe solution을 $30 \mu \mathrm{L}$ 첨가하여 5 분간 반응하여 흡광도 415 $\mathrm{nm}$ 에서 측정하였다. 측정된 값은 standard의 검량곡선에 근거하여 환산하였으며 $\mathrm{nmol} / \mathrm{g}$ 단위로 표현하였다.

\section{지방산}

지방산 분석은 증숙 및 건조처리 한 오징어 분말 $5 \mathrm{~g}$ 에 대하여 4 배량의 chloroform : methanol 혼합용매 $(2: 1, \mathrm{v} / \mathrm{v})$ 를 가하여 homogenizer(Ultra-Turrax ${ }^{\circledR}$ T25 digital, IKA, Germany)로 2분간 교반한 후, 여과하여 얻은 여액을 플라스 크에 넣고 evaporator(N1000, Eyela, Japan)로 용매를 제거하 여 지질을 추출하였다. 추출한 지질은 $14 \% \mathrm{BF} 3-\mathrm{methanol}$
(Sigma-Aldrich Co., MO, USA) $2 \mathrm{~mL}$ 를 가하고 30 분간 $85^{\circ} \mathrm{C}$ 에서 가열시킨 다음, 석유 ether로 추출하여 지방산 분석용 시료로 사용하였다. GC 분석조건은 HP-INNOWax capillary column $(30 \mathrm{~m} \times 0.32 \mathrm{~mm}$ i.d., film thickness $0.5 \mu \mathrm{m}$, Hewlett-Packard, MA, USA)이 정착된 gas chromatography (HP6890, CA, USA)로 carrier gas는 helieum을 사용하였다. Injector와 detector(flame ionization detector) 온도는 각각 $250^{\circ} \mathrm{C}, 270^{\circ} \mathrm{C}$ 로 설정하였고, oven 온도는 $170^{\circ} \mathrm{C}$ 에서 $225^{\circ} \mathrm{C}$ 까지 $1^{\circ} \mathrm{C} / \mathrm{min}$ 증가시켰다. 각 지방산은 동일조건에서 표준 지방산 methyl ester mixture(Sigma Chemical Co., MO, USA) 와 retention time을 비교하여 동정하였으며, 조성비는 각 peak의 면적을 상대적인 백분율로 나타내었다.

\section{유리 아미노산}

지방산 분석에 사용한 오징어 분말 $0.5 \mathrm{~g}$ 에 $70 \%$ ethanol 용액 $30 \mathrm{~mL}$ 를 넣고 잘 섞은 다음 $4{ }^{\circ} \mathrm{C}$ 에서 1 시간 방치한 후 30 분간 균질화 하였다. 시료액을 $4^{\circ} \mathrm{C}$ 에서 $10,192 \times \mathrm{g}$ 으로 20 분간 원심분리하여 얻은 상등액을 $40^{\circ} \mathrm{C}$ 에서 감압농축 시킨 후 증류수를 넣어 세척한 뒤 세척액을 여두기로 옮기 고, ethyl ether로 헹구어 여두기로 옮기는 과정을 2회 반복 하였다. 농축된 시료는 lithium citrate buffer(pH 2.20)로 25 $\mathrm{mL}$ 정용플라스크에 정용하고 sulfosalicylic acid(SigmaAldrich, Inc., MO, USA) $1 \mathrm{~g}$ 을 첨가하여 암실에서 1시간 방치시킨 후 원심분리 $(10,192 \times \mathrm{g}, 20$ 분 $)$ 하여 $0.45 \mu \mathrm{m}$ membrane filter로 여과한 시료액을 아미노산 자동분석기 (Biochrom 30, Biochrom Ltd., Cambridge, England)를 사용 하여 다음과 같은 조건으로 분석하였다. Cation separation column(lithium column, $4.6 \mathrm{~mm} \times 200 \mathrm{~mm}$ )을 사용하였고 이 동상의 유속은 $0.33 \mathrm{~mL} / \mathrm{min}$, ninhydrin 용액의 유속은 0.33 $\mathrm{mL} / \mathrm{min}$, column 온도는 $31-76^{\circ} \mathrm{C}$, 반응온도는 $135^{\circ} \mathrm{C}$ 로 하였 다.

\section{냄새 강도}

냄새강도는 Kang 등의 방법(19)에 따라 시료를 전처리한 후 간이 전자코(Odor concentration meter, XP-329, New Cosmos Electric Co., Ltd., Osaka, Japan)로 측정하였으며, 냄새의 강도(level)로 나타내었다.

\section{통계 처리}

실험 결과는 통계분석용 프로그램인 SPSS package $\operatorname{program}(18.0$, SPSS Inc, Chicago, IL, USA)을 사용하여 평 균과 표준편차를 구하였고, 세 집단이상의 평균치 분석은 one-way ANOVA 방법에 따라 실시하였으며, 유의성 검증 은 Duncan's multiple comparison test $(\mathrm{p}<0.05)$ 를 이용하여 검증하였다(20). 


\section{결과 및 고찰}

\section{오징어 가수분해물의 단백질 분해능}

오징어에 7 종의 효소를 시료 양의 $1 \%$ 농도로 처리하고 각 효소의 최적온도 및 $\mathrm{pH}$ 에서 8 시간 가수분해 시킨 후 단백질 분해능을 비교하였다. 단백질 분해능은 가수분해물 의 단백질 농도, ${ }^{\circ} \mathrm{Brix}$ 및 가수분해도로 확인하였다. Fig. 1 에 나타낸 것처럼 오징어 효소가수분해물의 단백질 농도 는 Protease NP (P-NP) 효소처리가 다른 효소 처리에 비해 높은 수준의 단백질 농도를 보였고, $\mathrm{Neu}>\mathrm{Pro}>\mathrm{Alc}>\mathrm{Fla}>$ Try $>$ Pep 효소처리 순으로 나타났다. ${ }^{\circ}$ Brix는 P-NP 가수분 해물의 가장 높았고, 그 다음이 $\mathrm{Neu}$ 와 Pro 순이었다. 오징어 효소가수분해물의 가수분해도를 측정한 결과는 Fig. 2에

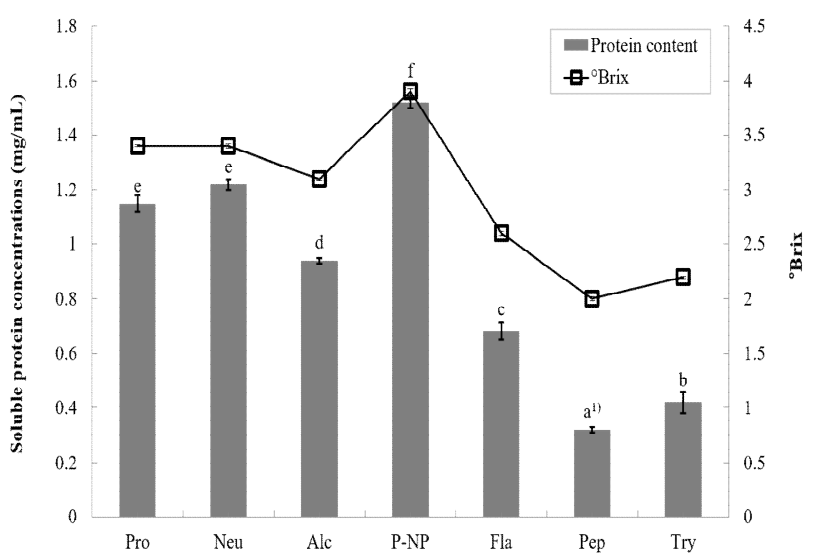

Fig. 1. Protein contents and ${ }^{\circ}$ Brix of squid hydrolysates by commercial proteases.

Pro, protamex; Neu, neutrase; Alc, alcalase; P-NP, protease NP; Fla, flavourzyme; Pep, pepsin; Try, trysin.

${ }^{2-1}$ Different letters within a row indicate significant difference $(\mathrm{p}<0.05)$.

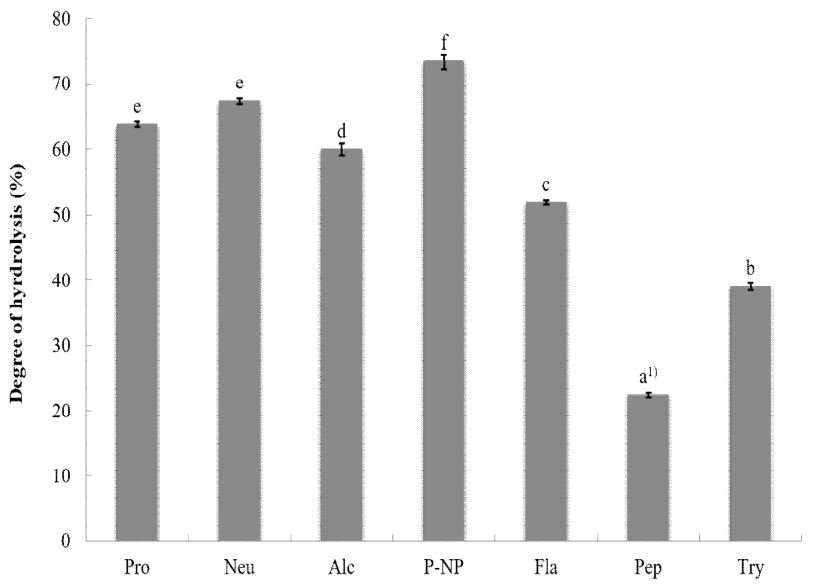

Fig. 2. Degree of hydrolysis of the enzymatic hydrolysates of squid by commercial proteases.

Pro, protamex; Neu, neutrase; Alc, alcalase; P-NP, protease NP; Fla, flavourzyme; Pep, pepsin; Try, trysin.

${ }_{1 \text { a-f }}$ Different letters within a row indicate significant difference $(\mathrm{p}<0.05)$.
나타내었다. 오징어 가수분해도는 P-NP 가수분해물 $(73.43 \pm 1.12 \%)>\mathrm{Neu}$ 가수분해물 $(67.43 \pm 0.43 \%)>\operatorname{Pro}$ 가수 분해물 $(63.86 \pm 0.39 \%)>\mathrm{Fla}$ 가수분해물 $(51.82 \pm 0.28 \%)>$ Try 가수분해물(39.04 $\pm 0.52 \%)>\operatorname{Pep}$ 가수분해물 $(22.42 \pm$ $0.32 \%)$ 의 순으로 나타났다. 시판 상업효소의 첨가에 따른 오징어 가수분해물의 단백질 농도와 ${ }^{\circ} \mathrm{Brix}$ 는 대체로 가수 분해도와 같은 경향을 나타내었으며, 가수분해도가 높은 것이 단백질 농도와 ${ }^{\circ} \mathrm{Brix}$ 도 높았다. 이상의 결과로부터, 첨가 효소 종류에 따른 오징어 단백질의 가수분해효소로 Protease NP를 사용하는 것이 적절하다고 판단되었다.

\section{$\mathrm{P}-\mathrm{NP}$ 효소의 최적조건}

7종의 효소 중 단백질 분해능이 가장 높은 것으로 확인된 $\mathrm{P}-\mathrm{NP}$ 효소의 최적농도와 가수분해 시간을 설정하기 위해 마쇄한 오징어의 육 중량대비 P-NP 효소를 각각 $0.05,0.5$, 1 및 $2 \%$ 의 농도로 처리하고 $\mathrm{pH}$ 7로 조정한 증류수를 오징 어 육 중량대비 10 배 가한 후, $50^{\circ} \mathrm{C}$ 에서 48 시간 동안 가수분 해 하였다. 오징어 가수분해물의 단백질 농도는 Fig. 3에서 처럼 P-NP 효소 농도가 $0.05 \%$ 및 $0.5 \%$ 인 경우보다 $1 \%$ 및 $2 \%$ 로 처리했을 때 시간경과에 따라 현저하게 높게 나타 나, P-NP 효소를 $1 \%$ 및 $2 \%$ 처리한 경우가 단백질 분해능이 높음을 알 수 있었다. 또한, 효소 농도를 $1 \%$ 와 $2 \%$ 로 처리한 오징어 가수분해물의 단백질 농도는 시간경과에 따라 유사 한 수준을 나타내었고, 효소처리 후 24시간 경과부터는 반 응시간이 경과할수록 단백질 분해능이 다소 증가하기는 하였으나 큰 차이를 보이지 않았다. 그러나 P-NP 효소 농도 를 $2 \%$ 로 하고 24 시간 이상 반응시켜 얻은 오징어 가수분해 물은 과도한 효소농도로 인해 쓴맛이 발생하였다. 한편, 단백질과 polypeptide 등이 아미노산이나 peptide의 형태로

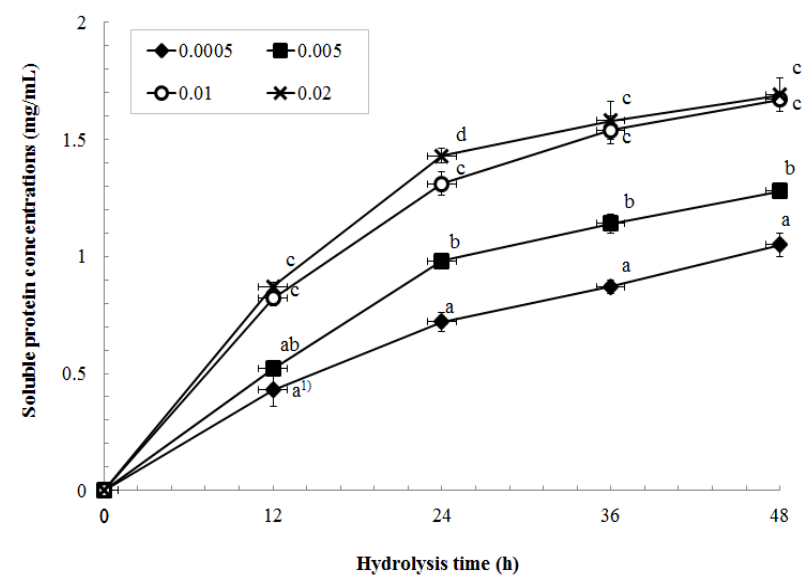

Fig. 3. Effects of incubation concentration and time of protease NP on the hydrolysis of squid.

\footnotetext{
A, squid hydrolysate with $0.05 \%$ protease NP; $\square$, squid hydrolysate with $0.5 \%$ protease $\mathrm{NP} ; \mathrm{O}$, squid hydrolysate with $1 \%$ protease $\mathrm{NP} ; \times$, squid hydrolysate with $2 \%$ protease NP.

1)a-d Different letters within a row indicate significant difference $(p<0.05)$
} 
분해되는 정도를 나타냄으로서 아미노산 함량을 나타내는 지표로 활용되는 아미노태 질소 함량은 효소 반응 시간이 증가할수록 증가하는 양상을 보였으나, 암모니아태 질소 함량도 급증하여 24시간 이상 가수분해를 진행한 경우에는 관능상 불쾌취가 유발되었다(data not shown).

\section{증숙 및 건조 처리한 오징어 분말의 특성}

오징어 육의 증숙온도는 $100^{\circ} \mathrm{C}$ 로 하고 증숙시간(1-2분, $8-10$ 분 및 20-30분) 및 건조온도 $\left(35^{\circ} \mathrm{C}, 50^{\circ} \mathrm{C}\right.$ 및 $\left.65^{\circ} \mathrm{C}\right)$ 을 달리하여 제조된 오징어 분말의 지방산과 유리아미노산 함량을 측정 한 결과를 Table 2와 3에 나타내었다. Table 2에 나타낸 것처럼, 증숙처리 하지 않고 건조처리만 한 오징어 분말 시료인 대조구의 불포화지방산 비율은 3.0-3.9 범위이었으 나, 증숙 및 건조처리를 한 오징어 분말의 불포화지방산
비율은 3.3-5.3 범위를 나타내었다. 증숙시간이 길어지고 건조온도가 높을수록 오징어 분말의 불포화지방산 비율이 높아지는 경향을 보였다. 즉, 오징어 분말 제조 시 20-30분 증숙한 오징어를 $50-65^{\circ} \mathrm{C}$ 의 온도에서 건조하면 불포화지방 산 비율이 가장 높은 오징어분말을 얻을 수 있었다. 한편, 대조구의 오징어 분말과 20-30분 증숙처리 하고, 각 온도별 로 건조한 오징어 분말의 유리아미노산 조성을 분석하여 Table 3에 나타내었다. 유리아미노산 총 조성은 대조구인 오징어 분말보다 증숙 및 건조처리한 실험구의 오징어 분말 에서 높게 나타났다. 특히 맛 성분 향상에 영향을 미치는 glutamic acid는 오징어를 증숙처리(20-30분) 및 건조처리 $\left(50^{\circ} \mathrm{C}\right.$ 이상 $)$ 한 오징어 분말에서 상당히 높은 조성을 보였으 며, alanine, leucine, lysine 및 arginine의 경우도 대조구보다 높은 조성을 나타내었다. 즉, 증숙 및 건조처리에 의해 고도

Table 2. Fatty acid composition (\%) of squid powder according to streaming and drying conditions

\begin{tabular}{|c|c|c|c|c|c|c|c|c|c|c|c|c|c|}
\hline & & \multicolumn{12}{|c|}{ Squid noodle } \\
\hline \multicolumn{2}{|c|}{ Condition } & \multicolumn{3}{|c|}{ Control } & \multicolumn{9}{|c|}{ Squid powder } \\
\hline \multicolumn{2}{|c|}{ Streaming temp } & \multicolumn{3}{|c|}{-} & \multicolumn{9}{|c|}{$100^{\circ} \mathrm{C}$} \\
\hline \multicolumn{2}{|c|}{ Steaming time } & \multicolumn{3}{|c|}{-} & \multicolumn{3}{|c|}{$1-2 \mathrm{~min}$} & \multicolumn{3}{|c|}{$8-10 \mathrm{~min}$} & \multicolumn{3}{|c|}{$20-30 \mathrm{~min}$} \\
\hline \multicolumn{2}{|c|}{ Drying temp } & $35^{\circ} \mathrm{C}$ & $50^{\circ} \mathrm{C}$ & $65^{\circ} \mathrm{C}$ & $35^{\circ} \mathrm{C}$ & $50^{\circ} \mathrm{C}$ & $65^{\circ} \mathrm{C}$ & $35^{\circ} \mathrm{C}$ & $50^{\circ} \mathrm{C}$ & $65^{\circ} \mathrm{C}$ & $35^{\circ} \mathrm{C}$ & $50^{\circ} \mathrm{C}$ & $65^{\circ} \mathrm{C}$ \\
\hline \multirow{19}{*}{$\begin{array}{l}\text { Fatty acid } \\
\qquad \%)\end{array}$} & $\mathrm{C} 14: 0$ & 0.82 & 0.75 & 0.76 & 0.93 & 0.68 & 0.70 & 0.81 & 1.04 & 0.83 & 0.72 & 0.84 & 0.82 \\
\hline & C15:0 & 0.47 & 0.37 & 0.37 & 0.42 & 0.40 & 0.49 & 0.37 & 0.45 & 0.44 & 0.38 & 0.38 & 0.44 \\
\hline & $\mathrm{Cl} 16: 0$ & 24.86 & 23.41 & 23.85 & 24.72 & 22.64 & 22.22 & 23.89 & 26.94 & 24.43 & 22.09 & 23.55 & 24.92 \\
\hline & $\mathrm{C} 17: 0$ & 1.08 & 0.89 & 1.04 & 1.01 & 0.00 & 1.24 & 0.98 & 1.06 & 0.94 & 1.08 & 0.89 & 0.74 \\
\hline & $\mathrm{C} 18: 0$ & 5.60 & 6.18 & 6.68 & 5.90 & 6.09 & 6.50 & 5.83 & 6.23 & 6.21 & 5.95 & 5.67 & 5.72 \\
\hline & SFA1) & 32.83 & 31.59 & 32.70 & 32.97 & 29.81 & 31.16 & 31.88 & 35.72 & 32.85 & 30.21 & 31.33 & 32.65 \\
\hline & $\mathrm{C} 18: \ln 9$ & 1.54 & 1.65 & 1.71 & 1.57 & 2.02 & 1.83 & 1.96 & 1.87 & 1.82 & 1.93 & 1.58 & 1.66 \\
\hline & $\mathrm{C} 18: \ln 7$ & 1.04 & 1.23 & 1.14 & 1.28 & 1.29 & 1.07 & 1.61 & 1.52 & 1.28 & 1.46 & 1.44 & 1.41 \\
\hline & $\mathrm{C} 20: \ln 11$ & 0.35 & 0.45 & 0.38 & 0.54 & 0.46 & 0.43 & 0.49 & 0.56 & 0.50 & 0.40 & 0.44 & 0.44 \\
\hline & $\mathrm{C} 20: \ln 9$ & 5.10 & 4.57 & 5.06 & 4.96 & 5.16 & 5.62 & 4.74 & 5.04 & 4.96 & 4.49 & 4.73 & 5.15 \\
\hline & MUFA $^{1)}$ & 8.04 & 7.90 & 8.29 & 8.34 & 8.93 & 8.96 & 8.80 & 8.99 & 8.56 & 8.28 & 8.19 & 8.66 \\
\hline & $\mathrm{C} 17: 2 \mathrm{n} 8$ & 0.76 & 0.77 & 0.82 & 0.91 & 1.01 & 1.13 & 0.66 & 0.98 & 0.89 & 1.06 & 0.77 & 0.81 \\
\hline & $\mathrm{C} 20: 4 \mathrm{n} 6$ & 2.53 & 2.28 & 2.43 & 2.21 & 2.70 & 2.43 & 0.49 & 2.42 & 2.21 & 2.38 & 2.42 & 2.33 \\
\hline & $\mathrm{C} 20: 3 \mathrm{n} 3$ & 0.42 & 0.63 & 0.58 & 0.32 & 0.66 & 0.60 & 0.00 & 0.56 & 0.58 & 0.56 & 0.51 & 0.36 \\
\hline & $\mathrm{C} 20: 5 \mathrm{n} 3$ & 12.34 & 12.93 & 12.48 & 13.16 & 13.47 & 12.50 & 13.51 & 0.00 & 12.84 & 13.48 & 13.25 & 12.99 \\
\hline & $\mathrm{C} 22: 5 \mathrm{n} 6$ & 0.40 & 0.47 & 0.47 & 0.39 & 0.55 & 0.54 & 0.52 & 0.54 & 0.43 & 0.52 & 0.40 & 0.42 \\
\hline & $\mathrm{C} 22: 5 \mathrm{n} 3$ & 0.35 & 0.45 & 0.34 & 0.45 & 0.32 & 0.39 & 0.44 & 0.57 & 0.32 & 0.47 & 0.39 & 0.48 \\
\hline & $\mathrm{C} 22: 6 \mathrm{n} 3$ & 42.33 & 42.99 & 41.89 & 41.26 & 42.55 & 42.28 & 43.71 & 50.21 & 41.33 & 43.05 & 42.73 & 41.30 \\
\hline & PUFA $^{1)}$ & 59.14 & 60.51 & 59.01 & 58.68 & 61.26 & 59.88 & 59.32 & 55.29 & 58.59 & 61.51 & 60.48 & 58.69 \\
\hline \multicolumn{2}{|c|}{ Crude lipid (\%) } & 4.51 & 5.01 & 5.72 & 5.18 & 4.67 & 4.83 & 7.29 & 7.21 & 6.95 & 7.16 & 7.73 & 7.85 \\
\hline \multicolumn{2}{|c|}{ SFA ratio ${ }^{2)}$} & 1.48 & 1.58 & 1.87 & 1.71 & 1.39 & 1.51 & 2.32 & 2.58 & 2.28 & 2.16 & 2.42 & 2.56 \\
\hline \multicolumn{2}{|c|}{ USFA $^{1)}$ ratio $^{3)}$} & 3.03 & 3.43 & 3.85 & 3.47 & 3.28 & 3.32 & 4.97 & 4.63 & 4.67 & 5.00 & 5.31 & 5.29 \\
\hline
\end{tabular}

${ }^{1)}$ SFA, saturated fatty acid; MUFA, monounsaturated fatty acid; PUFA, polyunsaturated fatty acid; USFA, unsaturated fatty acid

${ }^{2}$ SFA ratio, (SFA $\times$ crude lipid)/100

${ }^{3)}$ USFA ratio, (MUFA+PUFA) $\times$ crude lipid/100 
Table 3. Free amino acid contents of squid powder as affected by streaming and drying conditions

$(\mathrm{mg} / 100 \mathrm{~g})$

\begin{tabular}{|c|c|c|c|c|c|c|c|}
\hline & \multirow[b]{2}{*}{ Condition } & \multicolumn{6}{|c|}{ Squid noodle } \\
\hline & & \multicolumn{3}{|c|}{ Control } & \multicolumn{3}{|c|}{ Squid powder } \\
\hline \multicolumn{2}{|r|}{ Streaming temp } & \multicolumn{3}{|c|}{-} & \multicolumn{3}{|c|}{$100^{\circ} \mathrm{C}$} \\
\hline \multicolumn{2}{|r|}{ Steaming time } & \multicolumn{3}{|c|}{-} & \multicolumn{3}{|c|}{ 20-30 min } \\
\hline & Drying temp & $35^{\circ} \mathrm{C}$ & $50^{\circ} \mathrm{C}$ & $65^{\circ} \mathrm{C}$ & $35^{\circ} \mathrm{C}$ & $50^{\circ} \mathrm{C}$ & $65^{\circ} \mathrm{C}$ \\
\hline \multirow{21}{*}{$\begin{array}{l}\text { Free amino } \\
\text { acid }\end{array}$} & Phosphoserine & 56.14 & 62.30 & 48.88 & 64.03 & 126.00 & 167.47 \\
\hline & Taurine & 547.25 & 469.22 & 428.07 & 563.81 & 695.45 & 505.81 \\
\hline & Aspartic aicd & 101.79 & 377.01 & 489.48 & 160.91 & 711.62 & 512.96 \\
\hline & Threonine & 180.20 & 391.46 & 469.89 & 240.33 & 750.70 & 532.53 \\
\hline & Serine & 180.54 & 381.88 & 453.60 & 413.81 & 667.81 & 513.11 \\
\hline & Glutamic acid & 317.00 & 655.63 & 962.51 & 597.52 & 1740.01 & 1481.91 \\
\hline & Proline & 3392.45 & 3358.33 & 3353.17 & 3515.82 & 5620.91 & 4204.87 \\
\hline & Glycine & 478.46 & 436.04 & 542.96 & 584.76 & 821.67 & 731.22 \\
\hline & Alanine & 894.74 & 1089.23 & 1242.68 & 1255.34 & 2127.94 & 1745.31 \\
\hline & Valine & 185.29 & 548.93 & 678.80 & 654.32 & 961.64 & 794.53 \\
\hline & Cystine & 66.71 & 98.52 & 135.16 & 95.31 & 198.72 & 138.15 \\
\hline & Methionine & 140.97 & 401.59 & 493.85 & 278.74 & 735.03 & 639.67 \\
\hline & Isoleucine & 129.07 & 417.28 & 502.99 & 168.90 & 675.26 & 530.81 \\
\hline & Leucine & 280.18 & 981.63 & 1155.97 & 1177.75 & 1890.50 & 1598.29 \\
\hline & Tyrosine & 87.02 & 334.04 & 388.78 & 105.72 & 688.10 & 525.69 \\
\hline & Phenylalanine & 119.31 & 520.96 & 643.53 & 170.76 & 970.15 & 748.53 \\
\hline & Histidine & 324.30 & 202.47 & 313.49 & 79.03 & 440.51 & 448.61 \\
\hline & Ornithine & 60.61 & 104.67 & 150.65 & 60.27 & 141.16 & 102.01 \\
\hline & Lysine & 180.97 & 505.98 & 639.15 & 260.74 & 871.74 & 694.37 \\
\hline & Arginine & 434.29 & 527.64 & 701.45 & 571.13 & 1012.31 & 886.78 \\
\hline & Total & 8157.29 & 11864.81 & 13795.06 & 11019.00 & 21847.23 & 17502.63 \\
\hline
\end{tabular}

불포화지방산 조성이 높은 오징어 분말의 제조가 가능하였 으며, 이에 따라 유리아미노산 함량도 증가하여 맛과 풍미 가 향상된 오징어 분말의 제조가 가능함을 알 수 있었다.

\section{오징어 건면의 일반성분}

오징어 가수분해물과 오징어 분말의 첨가량을 달리하여 제조한 오징어 건면의 일반성분은 Table 4 와 같다. 오징어 가수분해물과 오징어 분말을 첨가하지 않은 대조구의 수분 함량은 $8.51 \%$ 였으나 오징어 가수분해물과 오징어 분말을 첨가한 $\mathrm{SN}$ 군에서는 오징어 분말 첨가량이 많아질수록 수 분함량이 낮게 나타났다. 조단백질 함량은 대조구보다 오 징어 가수분해물 및 오징어 분말을 첨가한 $\mathrm{SN}$ 군에서 유의 하게 높게 나타났다(p<0.05). 특히 대조구의 조단백질 함량 이 $10.7 \%$ 인데 비하여 오징어 분말을 $20 \%$ 첨가한 $\mathrm{SN} \mathrm{4}$ 의 경우는 $20.7 \%$ 로 약 2 배정도 높은 값을 나타내었다. 조지방 함량의 경우도 대조구는 $0.2 \%$ 이었고 $\mathrm{SN} 4$ 는 $0.8 \%$ 를 나타 내어 오징어 분말 첨가량이 많아질수록 조지방 함량도 높게
나타났다. 염도는 Table 1 에 나타낸 것처럼, 오징어 가수분 해물 및 오징어 분말이 가지는 자체 염도로 인해 오징어 건면 제조 시 소금을 대조구에 비해 적은 양을 첨가하였기 에 SN 1, SN 2 및 SN 3의 염도가 대조구보다 낮게 나타났다.

\section{오징어 건면의 색도}

오징어 가수분해물 및 오징어 분말의 첨가량을 달리하여 제조한 오징어 건면의 색도를 Table 5에 나타내었다. 명도 L값(lightness)은 대조구가 90.7으로 가장 높았고 SN $1, \mathrm{SN}$ $2, \mathrm{SN} 3$ 및 $\mathrm{SN} 4$ 는 86.6, 83.9, 82.6 및 78.6으로, 오징어 분말 첨가량이 증가할수록 $\mathrm{L}$ 값은 유의적으로 낮게 나타났 다(p<0.05). 적색도 $\mathrm{a}$ 값(redness)은 대조구가 -0.18 을 나타낸 반면 오징어 분말 첨가량이 증가할수록 $1.44,2.13,2.53$ 및 2.63을 나타내어 a값은 유의적으로 증가하는 경향을 보 였으며, 황색도 $\mathrm{b}$ 값(yellowness)의 경우도 오징어 분말 첨가 량이 증가할수록 유의적으로 증가하는 경향을 나타내었다 $(\mathrm{p}<0.05)$. 이는 $\operatorname{Kim}$ 등 $(21)$ 이 보고한 게살 분말을 첨가하여 
제조한 국수에서 게살 분말에 함유된 astaxanthin 색소로 인해 게살 분말 첨가군이 대조구에 비해 $\mathrm{L}$ 값이 낮고 $\mathrm{a}$ 값이 증가한다고 한 연구결과와 유사하였다. 본 연구에서도, 오 징어 건면에 첨가한 오징어 분말의 제조 시 사용되는 오징 어를 증숙처리 하면서 생긴 ommochrome의 발색과 건조처 리 하면서 발생된 Maillard 반응으로 인해 L값은 낮아지고 $\mathrm{a}$ 와 $\mathrm{b}$ 값은 증가한 것으로 생각되었다.
Table 6에 나타내었다. 수분결합능력은 시료와 수분과의 친화성을 나타내주는 것으로 이때 결합된 물은 시료입자에 의하여 흡수되거나 표면에 흡착하는 것으로 보고되어 있다 (22). SN 1, SN 2, SN 3 및 SN 4의 수분결합능력은 각각 $176.1 \%, 184.3 \%, 187.1 \%$ 및 $187.6 \%$ 로 오징어 분말의 첨가 량이 증가할수록 오징어 건면의 수분결합능력이 유의적으 로 증가하는 경향을 보였다 $(\mathrm{p}<0.05)$. 그러나 오징어 분말을

Table 4. Proximate composition of squid noodles containing squid hydrolysate and squid powder

\begin{tabular}{|c|c|c|c|c|c|}
\hline \multirow{2}{*}{ Composition (\%) } & \multicolumn{5}{|c|}{ Squid noodle ${ }^{1)}$} \\
\hline & Control & SN 1 & SN 2 & SN 3 & SN 4 \\
\hline Moisture & $8.5 \pm 0.0^{(2)}$ & $8.4 \pm 0.2^{\mathrm{bc}}$ & $8.2 \pm 0.2^{\mathrm{ab}}$ & $8.2 \pm 0.1^{\mathrm{a}}$ & $8.1 \pm 0.0^{\mathrm{a}}$ \\
\hline Crude protein & $10.7 \pm 0.1^{\mathrm{a}}$ & $14.4 \pm 0.0^{\mathrm{b}}$ & $15.7 \pm 0.0^{c}$ & $17.9 \pm 0.1^{\mathrm{d}}$ & $20.7 \pm 0.2^{\mathrm{e}}$ \\
\hline Crude lipid & $0.2 \pm 0.00^{\mathrm{a}}$ & $0.3 \pm 0.1^{\mathrm{a}}$ & $0.5 \pm 0.0^{\mathrm{b}}$ & $0.7 \pm 0.0^{c}$ & $0.8 \pm 0.0^{c}$ \\
\hline Ash & $0.6 \pm 0.1^{\mathrm{a}}$ & $0.7 \pm 0.1^{\mathrm{b}}$ & $0.7 \pm 0.0^{\mathrm{b}}$ & $0.8 \pm 0.0^{b}$ & $0.9 \pm 0.1^{\mathrm{c}}$ \\
\hline Carbohydrate $^{3)}$ & 80.0 & 76.2 & 74.9 & 72.4 & 69.5 \\
\hline Salinity & $2.1 \pm 0.0^{\mathrm{d}}$ & $1.3 \pm 0.0^{\mathrm{a}}$ & $1.7 \pm 0.0^{\mathrm{b}}$ & $1.8 \pm 0.0^{\mathrm{c}}$ & $2.6 \pm 0.1^{\mathrm{e}}$ \\
\hline
\end{tabular}

${ }^{1)}$ Control, squid noodle without squid hyrolysate and squid powder; SN 1, squid noodle with squid hyrolysate $45 \%$ and squid powder $5 \%$ based on wheat flour weight; SN

2, squid noodle with squid hyrolysate $45 \%$ and squid powder $10 \%$ based on wheat flour weight; SN 3 , squid noodle with squid hyrolysate $45 \%$ and squid powder $15 \%$

based on wheat flour weight; SN 4, squid noodle with squid hyrolysate $45 \%$ and squid powder $20 \%$ based on wheat flour weight.

2)a-e Different letters within a row indicate significant difference $(p<0.05)$.

${ }^{3)}$ Carbohydrate $(\%)=100$-(moisture+crude protein+crude lipid + ash)

Table 5. Hunter's color value of squid noodles containing squid hydrolysate and squid powder

\begin{tabular}{cccccc}
\hline \multirow{2}{*}{ Color values } & \multicolumn{5}{c}{ Squid noodle } \\
\cline { 2 - 6 } & Control & SN 1 & SN 2 & SN 3 & SN 4 \\
\hline L value & $90.73 \pm 0.11^{\mathrm{e} 2)}$ & $86.56 \pm 0.03^{\mathrm{d}}$ & $83.88 \pm 0.02^{\mathrm{c}}$ & $82.61 \pm 0.03^{\mathrm{b}}$ & $78.60 \pm 0.02^{\mathrm{a}}$ \\
a value & $-0.18 \pm 0.02^{\mathrm{a}}$ & $1.44 \pm 0.02^{\mathrm{b}}$ & $2.13 \pm 0.03^{\mathrm{c}}$ & $2.53 \pm 0.03^{\mathrm{d}}$ & $2.63 \pm 0.03^{\mathrm{e}}$ \\
b value & $9.73 \pm 0.02^{\mathrm{b}}$ & $9.32 \pm 0.01^{\mathrm{a}}$ & $9.96 \pm 0.05^{\mathrm{c}}$ & $10.71 \pm 0.01^{\mathrm{d}}$ & $13.43 \pm 0.01^{\mathrm{e}}$ \\
\hline
\end{tabular}

${ }^{1)}$ Control, squid noodle without squid hyrolysate and squid powder; SN 1, squid noodle with squid hyrolysate $45 \%$ and squid powder $5 \%$ based on wheat flour weight; SN 2, squid noodle with squid hyrolysate $45 \%$ and squid powder $10 \%$ based on wheat flour weight; SN 3, squid noodle with squid hyrolysate $45 \%$ and squid powder $15 \%$ based on wheat flour weight; SN 4, squid noodle with squid hyrolysate $45 \%$ and squid powder $20 \%$ based on wheat flour weight.

${ }^{2) \text { a- }}$ Different letters within a row indicate significant difference $(\mathrm{p}<0.05)$.

Table 6. Water-binding capacity(WBC), solubility and swelling power of squid noodle containing squid hydrolysate and squid powder

\begin{tabular}{cccccc}
\hline & \multicolumn{5}{c}{ Squid noodle } \\
\cline { 2 - 6 } & Control & SN 1 & SN 2 & SN 3 & SN 4 \\
\hline WBC (\%) & $183.2 \pm 1.8^{\mathrm{b} 2)}$ & $176.1 \pm 1.6^{\mathrm{a}}$ & $184.3 \pm 0.7^{\mathrm{b}}$ & $187.1 \pm 0.2^{\mathrm{c}}$ & $187.6 \pm 0.1^{\mathrm{c}}$ \\
Solubility (\%) & $12.7 \pm 0.1^{\mathrm{c}}$ & $11.1 \pm 0.7^{\mathrm{b}}$ & $10.9 \pm 0.7^{\mathrm{b}}$ & $8.4 \pm 0.8^{\mathrm{a}}$ & $7.5 \pm 0.5^{\mathrm{a}}$ \\
Swelling power (\%) & $6.5 \pm 0.2^{\mathrm{c}}$ & $6.0 \pm 0.2^{\mathrm{b}}$ & $5.8 \pm 0.1^{\mathrm{b}}$ & $5.1 \pm 0.4^{\mathrm{a}}$ & $4.7 \pm 0.3^{\mathrm{a}}$ \\
\hline
\end{tabular}

${ }^{1)}$ Control, squid noodle without squid hyrolysate and squid powder; SN 1, squid noodle with squid hyrolysate $45 \%$ and squid powder $5 \%$ based on wheat flour weight; SN

2 , squid noodle with squid hyrolysate $45 \%$ and squid powder $10 \%$ based on wheat flour weight; SN 3, squid noodle with squid hyrolysate $45 \%$ and squid powder $15 \%$ based on wheat flour weight; SN 4, squid noodle with squid hyrolysate $45 \%$ and squid powder $20 \%$ based on wheat flour weight.

${ }^{2) a-c}$ Different letters within a row indicate significant difference $(\mathrm{p}<0.05)$.

오징어 건면의 수분결합능력, 용해도 및 팽윤력

오징어 가수분해물 및 오징어 분말의 첨가량을 달리하여 제조한 오징어 건면의 수분결합능력, 용해도 및 팽윤력을
첨가하지 않은 대조구의 수분결합능력이 $183.23 \%$ 인 점을 감안하면 오징어 분말을 첨가한 오징어 건면과 수분결합능 력은 대조구와 유사한 수준을 나타내는 것으로 판단되었 
다. 한편 오징어 가수분해물과 오징어 분말을 사용한 오징 어 건면의 용해도와 팽윤력을 측정한 결과, 오징어 분말을 첨가하지 않은 대조구가 가장 높은 값을 나타내었고, 첨가 량이 많은 오징어 건면 시료일수록 낮은 값을 나타내었다. 이처럼 용해도와 팽윤력에서 차이를 나타낸 이유는 오징어 분말의 첨가로 인해 밀가루와 같은 전분의 함량이 적어짐에 따른 것으로 판단되었다.

\section{오징어 건면의 조리특성}

오징어 가수분해물 및 오징어 분말의 첨가량을 달리하여 제조한 오징어 건면의 조리특성을 Table 7에 나타내었다. 오징어 분말의 첨가량이 증가할수록 조리 후 오징어 건면의 중량과 부피가 유의적으로 증가하였다 $(\mathrm{p}<0.05)$. 조리 후 국 수의 증량증가는 부피의 증가와 정의 상관관계를 보인다고 한 연구결과와 일치하였다(23). 수분흡수율은 대조구가 $135.6 \%$ 를 나타낸 것에 비해, 오징어 분말을 첨가한 오징어 건면 시료에서는 142.0-202.1\% 수준을 나타내어 유의적으 로 높은 값을 보였으며 $(\mathrm{p}<0.05)$, 오징어 분말 첨가량이 증가 할수록 수분흡수율 값이 높게 나타났다. 한편, 조리 중 고형 분의 손실 정도를 나타내는 국물의 탁도는 대조구가 0.90 으 로 가장 낮았고 오징어 분말 첨가량이 많아짐에 따라 용출 성분들이 유의하게 증가하여 오징어 분말 $20 \%$ 첨가군이 2.15 로 가장 높은 값을 보였다(p<0.05). 이는 홍어분말(24), 파래분말(25) 및 새우분말(26)을 첨가한 국수에서 분말양 이 증가할수록 국물의 탁도를 측정한 흡광도 값이 증가하는 경향을 나타내었다고 한 연구결과와 일치하는 경향을 보였 다. 즉, 국수 제조 시 분말과 같은 첨가물의 양이 많아질수록 조리 중 고형분의 손실양이 커져 국물의 탁도가 높게 나타 난 것으로 생각되었다.
제조한 오징어 건면에 어느 정도 함유되어 있는지 살펴본 결과를 Fig. 4에 나타내었다. 오징어 분말 첨가량이 많아질 수록 타우린 함량은 증가하는 경향을 보였고, 오징어 가수 분해물과 오징어 분말을 첨가하지 않은 대조구에서는 타우 린이 전혀 검출되지 않았다. 이 결과로부터 오징어 가수분 해물과 오징어 분말을 사용하여 제조한 오징어 건면은 영양 학적 기능 외에 생리활성 기능을 갖는 장점도 있을 것으로 예측되었다.

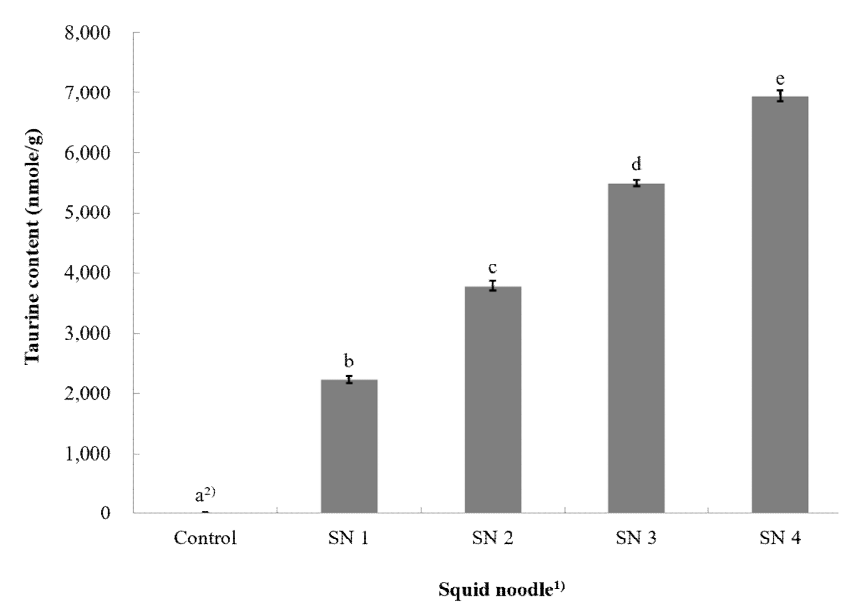

Fig. 4. Taurine content of squid noodles containing squid hydrolysate and squid powder.

${ }^{1)}$ Control, squid noodle without squid hyrolysate and squid powder; SN 1, squid noodle with squid hyrolysate $45 \%$ and squid powder $5 \%$ based on wheat flour weight; SN 2, squid noodle with squid hyrolysate $45 \%$ and squid powder $10 \%$ based on wheat flour weight; SN 3, squid noodle with squid hyrolysate $45 \%$ and squid powder $15 \%$ based on wheat flour weight; SN 4, squid noodle with squid hyrolysate $45 \%$ and squid powder $20 \%$ based on wheat flour weight.

2)a-e Different letters within a row indicate significant difference $(p<0.05)$.

Table. 7. Characteristics of the cooking of squid noodles containing squid hydrolysate and squid powder

\begin{tabular}{cccccc}
\hline & \multicolumn{5}{c}{ Squid noodle ${ }^{1 \mathrm{l}}$} \\
\cline { 2 - 6 } & Control & SN 1 & SN 2 & SN 3 & SN 4 \\
\hline Pre-cook weight(g) & $50.00 \pm 0.15^{\mathrm{a} 2)}$ & $50.00 \pm 0.13^{\mathrm{a}}$ & $50.00 \pm 0.12^{\mathrm{a}}$ & $50.00 \pm 0.25^{\mathrm{a}}$ & $50.00 \pm 0.12^{\mathrm{a}}$ \\
Post-cook weight(g) & $119.07 \pm 1.13^{\mathrm{a}}$ & $123.60 \pm 1.73^{\mathrm{b}}$ & $127.64 \pm 1.71^{\mathrm{c}}$ & $135.65 \pm 2.82^{\mathrm{d}}$ & $151.45 \pm 3.03^{\mathrm{e}}$ \\
Post-cook volume(mL) & $405.10 \pm 2.25^{\mathrm{a}}$ & $410.70 \pm 2.04^{\mathrm{ab}}$ & $415.50 \pm 2.25^{\mathrm{bc}}$ & $420.70 \pm 3.23^{\mathrm{c}}$ & $440.40 \pm 3.11^{\mathrm{d}}$ \\
Water absorption(\%) & $135.55 \pm 2.25^{\mathrm{a}}$ & $142.02 \pm 3.20^{\mathrm{b}}$ & $149.64 \pm 3.08^{\mathrm{c}}$ & $164.68 \pm 5.12^{\mathrm{d}}$ & $202.11 \pm 4.75^{\mathrm{e}}$ \\
Turbidity(OD $\left(\mathrm{OD}_{67 \mathrm{~mm}}\right)$ & $0.90 \pm 0.02^{\mathrm{a}}$ & $0.93 \pm 0.01^{\mathrm{a}}$ & $1.68 \pm 0.03^{\mathrm{b}}$ & $1.89 \pm 0.01^{\mathrm{c}}$ & $2.15 \pm 0.07^{\mathrm{d}}$ \\
\hline
\end{tabular}

${ }^{11}$ Control, squid noodle without squid hyrolysate and squid powder; SN 1, squid noodle with squid hyrolysate $45 \%$ and squid powder $5 \%$ based on wheat flour weight; SN 2 , squid noodle with squid hyrolysate $45 \%$ and squid powder $10 \%$ based on wheat flour weight; SN 3, squid noodle with squid hyrolysate $45 \%$ and squid powder $15 \%$ based on wheat flour weight; SN 4, squid noodle with squid hyrolysate $45 \%$ and squid powder $20 \%$ based on wheat flour weight.

${ }^{2) a-e}$ Different letters within a row indicate significant difference $(\mathrm{p}<0.05)$.

\section{오징어 건면의 타우린 함량}

오징어에 다량 함유되어 있는 타우린은 함황 아미노산 일종으로 체내 콜레스테롤 대사, 면역 증강 작용, 해독작용 등의 생리활성 기능을 갖는 것으로 알려져 있다(27). 이러한 타우린이 오징어 가수분해물과 오징어 분말을 첨가하여

\section{오징어 건면의 냄새강도}

오징어 가수분해물과 오징어 분말의 첨가량을 달리하여 제조한 오징어 건면의 냄새 강도 특성을 살펴보기 위하여 대조군과 비교한 결과를 Fig. 5에 나타내었다. 오징어 가수 분해물과 오징어 분말을 첨가하지 않은 대조구는 $116 \pm 2.5$ 
level이었고, 오징어 가수분해물과 오징어 분말을 첨가한 $\mathrm{SN} 1, \mathrm{SN} 2, \mathrm{SN} 3$ 및 $\mathrm{SN} 4$ 시료는 각각 $138 \pm 4.8$ level, $189 \pm 7.8$ level, $200 \pm 11.4$ level및 $278 \pm 8.2$ level를 나타냄으로 서, 대조구 보다 오징어 가수분해물과 오징어 분말을 첨가 한 $\mathrm{SN}$ 시료에서 냄새강도가 유의적으로 높았고 오징어 분 말 첨가량이 많아질수록 냄새강도가 높은 값을 나타내었 다. 이상의 결과로부터 대조구에 비해 오징어 분말 첨가량 이 높을수록 오징어의 풍미가 강한 오징어 건면의 제조가 가능하였다.

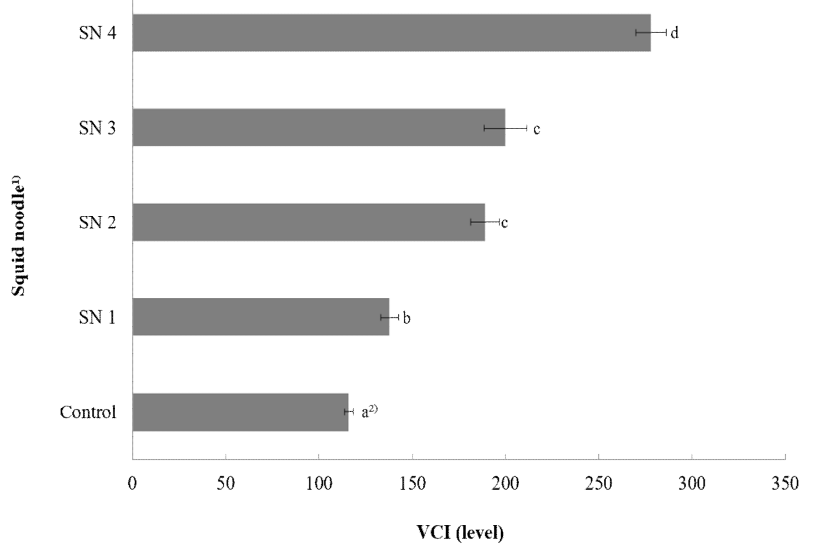

Fig. 5. Volatile component intensity (VCI) of squid noodles containing squid hydrolysate and squid powder.

${ }^{1)}$ Control, squid noodle without squid hyrolysate and squid powder; SN 1, squid noodle with squid hyrolysate $45 \%$ and squid powder $5 \%$ based on wheat flour weight; SN 2 , squid noodle with squid hyrolysate $45 \%$ and squid powder $10 \%$ based on wheat flour weight; SN 3, squid noodle with squid hyrolysate $45 \%$ and squid powder $15 \%$ based on wheat flour weight; SN 4, squid noodle with squid hyrolysate $45 \%$ and squid powder $20 \%$ based on wheat flour weight.

${ }^{2) a-d}$ Different letters within a row indicate significant difference $(p<0.05)$.

\section{요 약}

오징어 효소가수분해물과 증숙 및 건조처리를 한 오징어 분말을 첨가하여 제조한 오징어 건면에서 protease NP를 사용하여 오징어 가수분해물을 제조했을 때 오징어의 가용 성 단백질 농도, ${ }^{\circ} \mathrm{Brix}$ 및 가수분해도가 가장 높은 값을 나타내었으며, 사용량은 오징어 중량의 $1 \%$ 이었고 $50^{\circ} \mathrm{C}$ 에 서 24시간 가수분해 하는 것이 적절하였다. 오징어 건면의 일반성분은, 오징어 분말 함량의 증가에 따라 조단백질과 조지방 함량도 유의적으로 증가하는 경향을 보였다. 오징 어 건면의 $\mathrm{L}$ 값은 대조구보다 낮았으나, 오징어 분말 첨가량 이 증가할수록 $\mathrm{a}$ 와 $\mathrm{b}$ 값은 유의적으로 증가하였다. 용해도 와 팽윤력은 오징어 가수분해물과 오징어 분말을 첨가한 오징어 건면 시료군이 대조군보다 유의적으로 낮은 값을 나타내었다. 오징어 건면의 조리특성(중량, 부피, 수분흡수 율 및 탁도)을 조사한 결과, 오징어 가수분해물과 오징어 분말을 첨가한 시료군에서 높은 값을 나타내었고, 오징어
분말 첨가량이 증가할수록 조리특성 값이 유의적으로 증가 하는 경향을 보였다. 또한 오징어 건면의 냄새강도는 오징 어 분말 첨가량이 증가할수록 높게 나타났다. 관능평가 결 과, 오징어 분말 첨가량이 $5 \%$ 및 $10 \%$ 인 경우에 거의 모든 항목에서 유의적으로 높은 점수를 받았다. 이상의 결과를 종합하여 볼 때, 오징어 효소가수분해물과 증숙 및 건조처 리 한 오징어 분말을 사용함으로서 영양학적 장점 뿐만 아니라 맛과 풍미가 우수한 오징어 건면의 제조가 가능하였 고, 오징어 산업의 고부가가치 창출 및 맛과 건강을 중시하 는 소비자의 기호에도 충족될 것으로 생각되었다.

\section{감사의 글}

본 연구는 국립수산과학원(R2019054)의 지원에 의해 운 영되었습니다.

\section{References}

1. NIFS (2018) Composition table of marine products in korea. $8^{\text {th }}$ ed. National Institute Fisheries Science, Busan, Korea, p 264-265

2. Food Information Statistics System. http://www.atfis.or.kr/ article/M001050000/view.do? articleld=1913\&boardle $=$ $3 \&$ page $=2 \&$ searchKey $=\&$ searchstring $=\&$ searchCategor $y=$ (accessed November 2015)

3. Jeong CH, Kim JH, Cho JR, Ahn CG, Shim KH (2007) Quality characteristics of wet noodles added with korean paprika powder. J Korean Soc Food Sci Nutr, 36, 779-784

4. Jung BM, Park SO, Shin TS (2009) Development and quality characteristics of rice noodles made with added Capsosiphon fulvescens powder. Korean J Food Cookery Sci, 25, 180-188

5. Kim GB (2012) Instant rice noodle using the extract of yacorn and hovenia dulcis, and manufacturing method thereof. Korea Patent No. 1145327

6. Hwang SY, Kang KO (2013) Quality characteristics of rice noodles supplemented with tumeric, purple sweet potato, or seaweed(Hizikia fusiforme). J East Asian Soc Dietary Life, 23, 211-217

7. Kim CB, Lee SH, Kim MY, Yoon JT, Cho RK (2002) Effects of the addition of leek and dropwort powder on the quality of noodles. Korean J Food Preserv, 9, 36-41

8. Yoon EK, Jo SY (1999) Preparation of cuttle fish-containing noodle. Korea Patent No. 0193594

9. Choi KP, Jo SH, Lee BS, Yun JS, Byun KS, Lee YW, 
Jo JH (2006) Squid and mulberry leaves with the main materialnoodles manufacturing method. Korea Patent No. 0663770

10. Ban JH (2008) Squid ink containing noodle. Korea Patent No. 0801170

11. Jo JH, Lee HY, Kim GD (2008) Noodle including squid and manufacturing method thereof. Korea Patent No. 0822815

12. Ryu TH, Kim JH, Shin JY, Kim SH, Yang JY (2015) Optimization of hydrolysis using oyster and oyster cooking drip. J Life Science, 25, 795-800

13. Noh KH, Min KH, Seo BY, Kim SH, Seo YW, Song YS (2012) Characteristics of protein from red crab (Chionoecetes japonicus) shell by commercial proteases. Korean J Nutr, 45, 429-436

14. Sargent MG (1987) Fiftyfold amplification of the lowry protein assay. Anal Biochem, 163, 476-481

15. Kang KT, Heu MS, Kim JS (2007) Improvement on the quality and Functionality of red tanner crab cooking drip using commercial enzymes. J Korean Soc Food Sci Nutr, 36, $1022-1030$

16. AOAC (2005) Official Methods of Analysis. $18^{\text {th }} \mathrm{ed}$, Association of Official Analytical Chemists, Washington DC, USA, p 33-36

17. Chen SY, Kim KH, Yook HS (2016) Quality characteristics of wet noodles with Allium hookeri powder. J Korean Soc Food Sci Nutr, 45, 84-90

18. Park BH, Cho HS (2006) Quality characteristics of dried noodle made with Dioscorea japonica flour. Korean J Food Cookery Sci, 22, 173-180
19. Kang SI, Kim KH, Lee JK, Kim YJ, Park SJ, Kim MW, Choi BD, Kim DS, Kim JS (2014) Comparison of the food quality of freshwater rainbow trout Oncorhhynchus mykiss cultured in different regions. Korean J Fish Aquat Sci, 47, 103-113

20. Duncan DB (1955) Multiple-range and multiple F tests. Biometrics, 11, 1-42

21. Kim BM, Jung MJ, Kim JC, Jun JY, Kim DS, Jeong IH (2016) Effects of red snow crab Chionoecetes japonicus leg meat powder on the quality characteristics of noodles. Korean J Fish Aquat Sci, 49, 285-292

22. Park BH, Joo HM, Cho HS (2014) Quality characteristics of dried noodles added with Ligularia fischeri powder. Korean J Food Culture, 29, 205-211

23. Kim SK, Kim HR, Bang JB (1996) Effects of alkaline reagent on the rheological properties of wheat flour and noodle property. Korean J Food Sci Technol, 28, 58-65

24. Cho HS, Kim HS (2008) Quality characteristics of Mandupi with skate(Raja kenojei) flour. Korean J Food Culture, 23, 252-257

25. Park BH, Ju SM, Cho HS (2010) Effect of enteromorpha intenstinalis powder addition in the quality of dumpling shell. Korean J Food Preserv, 17, 814-819

26. Cho HS, Kim KH (2009) Assessment of quality characteristics of dried shrimp noodles for elderly foodservice operations. Korean J Food Cookery Sci, 25, 267-274

27. Cho SY, Joo DS, Park SH, Kang HJ, Jeon JK (2000) Change of taurine content in squid meat during squid processing and taurine content in the squid processing waste water. J Korean Fish Soc, 33, 51-54 